\title{
Efficacy of entomopathogenic nematodes against Spodoptera littoralis (Boisd.) and Agrotis ipsilon (H.) (Lepidoptera: Noctuidae)
}

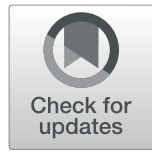

\author{
Hassan M. Sobhy', Nagwa A. Abdel-Bary², Farid A. Harras ${ }^{3}$, Farha H. Faragalla ${ }^{3}$ and Hussein I. Husseinen ${ }^{3 *}$
}

\begin{abstract}
The study aimed to evaluate the efficacy of the EPNs against the larvae of Egyptian cotton leaf worm Spodoptera littoralis (Boisduval) and the black cutworm Agrotis ipsilon (Hufnagel) (Lepidoptera: Noctuidae) in vitro before in vivo study. The susceptibility of both larval species to the entomopathogenic nematode species, Steinernema monticolum and Heterorhabditis bacteriophora, was evaluated under laboratory conditions. The concentration of 400 IJs/dish for S. monticolum achieved up to 97.77 and $95.55 \%$ mortality rates of the 5 larval instars from 2 nd to 6 th instars of S. littoralis and A. ipsilon, respectively after $72 \mathrm{~h}$. The concentration of $800 \mathrm{lJs} /$ dish recorded larval mortality rates of 41.86 to $100 \%$ against 2 nd to 6 th instars of $A$. ipsilon larvae, after $72 \mathrm{~h}$. At the lowest concentration (50 IJs/ dish), the larvae of $\mathrm{S}$. littoralis were more susceptible to $\mathrm{H}$. bacteriophora than the larvae of A. ipsilon. The data indicated that $200 \mathrm{IJ} /$ dish was the most effective concentration for all larval stages of both insect pests because the mortality percentage was $100 \%$.
\end{abstract}

Keywords: Entomopathogenic nematode, Spodoptera littoralis, Agrotis ipsilon, Steinernema monticolum, Heterorhabditis bacteriophora, Biological control, Basil

\section{Introduction}

The Egyptian cotton leaf worm, Spodoptera littoralis (Boisd.), and the black cutworm, Agrotis ipsilon (Hufnagel) (Lepidoptera: Noctuidae), are the most important insect pests on many crops as they cause economic losses (El-Sheikh et al. 2013). Extensive studies have been conducted in the field of biological control of insect pests, using many bio-control agents such as entomopathogenic nematodes (EPNs). The Heterorhabditidae and Steinernematidae families live in soils and are deadly parasites to a wide range of insects (Stuart et al. 1997; Orozco R.A. et. al. 2014). They are environmentally safe agent as they do not cause any harmful effects either to humans or farm animals and are beneficial insects (van Zy C. and Malan A.P. 2014).

\footnotetext{
* Correspondence: Husseinibrahem112@yahoo.com

${ }^{3}$ Department of Vegetable, Medicinal, Aromatic and Ornamental Plant Pests, Plant Protection Research Institute, Agricultural Research Center, Giza, Egypt Full list of author information is available at the end of the article
}

Heterorhabditidae and Steinernematidae have a symbiotic association with the entomopathogenic bacteria genera Photorhabdus and Xenorhabdus, respectively, and both effectively parasitize and kill their insect hosts (Ehlers 2001). When encountering a suitable host, the infective juveniles (IJs) enter the host via natural openings such as the spiracles, mouth, or anus (Griffin et al. 2005; Atwa A. 2011; Atwa A. 2014; and Gozel and Gozel, 2016). The bacteria grow rapidly in the hemolymph of insect host and produce toxins that kill the host by means of inducing septicemia within 24 to $72 \mathrm{~h}$ of infection (Ehlers 2001 and Griffin et al. 2005). Since the first use of the EPN, Steinernema glaseri against the white grub Popillia japonica in New Jersey (USA) (Glaser and Farrell 1935), no inferior hazards or damages have been recorded by the EPNs to the environment. The application of EPNs is widespread in many parts of the world and could be grown experimentally in large quantities at relatively low costs (Shapiro-Ilan et al. 2006 and Mutegi et al. 2018).

\section{Springer Open}

(๑) The Author(s). 2020 Open Access This article is licensed under a Creative Commons Attribution 4.0 International License, which permits use, sharing, adaptation, distribution and reproduction in any medium or format, as long as you give appropriate credit to the original author(s) and the source, provide a link to the Creative Commons licence, and indicate if changes were made. The images or other third party material in this article are included in the article's Creative Commons licence, unless indicated otherwise in a credit line to the material. If material is not included in the article's Creative Commons licence and your intended use is not permitted by statutory regulation or exceeds the permitted use, you will need to obtain permission directly from the copyright holder. To view a copy of this licence, visit http://creativecommons.org/licenses/by/4.0/. 
Numerous issues indicated that the EPNs are also potent and effective for selected insect species; therefore, they are used as a biocontrol agent, instead of pesticides.

Therefore, the present study aimed to evaluate the efficacy of the two EPNs S. monticolum and H. bacteriophora against $S$. littoralis and $A$. ipsilon larvae under laboratory conditions.

\section{Materials and methods}

The study was carried out under laboratory conditions in 2019, to evaluate the efficacy of the EPNs against $S$. littoralis and A. ipsilon larvae under laboratory conditions in the Vegetables Pests Research Department, Plant Protection Research Institute, Agricultural Research Center, Giza, Egypt.

\section{Rearing of Spodoptera littoralis}

The field strain of $S$. littoralis was obtained from an openfield tomato farm at Giza Governorate, Egypt, was transferred to the laboratory of Vegetables Pests Research Department, Plant Protection Research Institute, Agricultural Research Center, Giza, Egypt, and was reared at $25^{\circ} \mathrm{C} \pm 2$ ${ }^{\circ} \mathrm{C}$ and $65-75 \mathrm{RH} \%$ for mass production. S. littoralis adults were placed in glass jars and fed on castor bean leaves (Ricinus communis L.) (Zhang et al. 2019a). The jars were provided every day with castor bean leaves as a source of food for the larvae. The 6th larval instar was allowed to pupate in larger jars, containing dry saw dust. The pupae were transferred to Petri dishes containing tissue paper and kept in suitable cages for mating after extruding of moths from pupae. The emerging adults were fed on $20 \%$ honey solution and allowed to lay their eggs on the provided leaves of Nerium oleander as a physical surface for moth mating, oviposition, and resting processes.

\section{Rearing of Agrotis ipsilon}

Twenty individuals of newly emerged A. ipsilon moths were obtained from the cutworm department, transferred to the laboratory of Vegetables Pests Research Department, Plant Protection Research Institute, Agricultural Research Center, Giza, Egypt, and kept in glass jars covered with pieces of tissue secured in position by rubber bands. Honey solution of $20 \%$ concentration was used as food for adults. Females allowed to lay their eggs on muslin strips that were fixed on the top of the jars. These strips were transferred into Petri dishes and, after egg-laying, kept in an incubator under constant temperature of $25{ }^{\circ} \mathrm{C} \pm 1{ }^{\circ} \mathrm{C}$ and $70-80 \mathrm{RH} \%$ (Zhang et al. 2019b), until hatching. The newly hatched larvae were transferred into small glass jars and provided daily with castor leaves as a source of food. The 4thinstar larvae were separated individually or in small groups in a glass plate to avoid cannibalism.
Susceptibility of S. littoralis and A. ipsilon larvae to EPNs Two species of nematodes were used in the present study, Heterorhabditis bacteriophora (Poinar 1990) (strain HP88) and a Korean species, Steinernema monticolum (Stock et al. 1997), according to Ibraheem (2015). Both nematode species were reared at $26^{\circ} \mathrm{C}$ on late-instar larvae of the greater wax moth, Galleria mellonella (L.) (Lepidoptera: Galleridae), following the method of Woodring and Kaya (1998). The nematode infective juveniles (IJs) that emerged from insect cadavers were recovered, using modified White traps (Kaya and Stock 1997). After storage at $10{ }^{\circ} \mathrm{C}$ for 1 week, they were allowed to acclimatize at room temperature for 45-60 min and their viability was checked by observation of movement under the zoom stereomicroscope (Ibraheem 2015).

\section{Petri dish assays}

Petri dishes containing 2 moist filter papers with $5 \mathrm{~cm}^{3}$ water were used for bioassays of the larvae 2nd, 3rd, 4th, 5th, and 6th instars of S. littoralis and A. ipsilon. The 1st-instar larvae of both species were excluded in this test due to the difficulty of handling them. Ten individuals/dish were exposed to the IJs of each nematode species. Six nematode concentrations 50, 100, 200, 400, 800, and $1600 \mathrm{IJs} /$ dish were used. The basil leaves were used as food for the larvae. Petri dishes were maintained in an incubator at $26 \pm 2{ }^{\circ} \mathrm{C}$. Four hundred and eighty dishes were used in the experiments including 2 nematode species $\times 6$ concentrations $\times 2$ insect species $\times 5$ instars $\times 4$ Petri dishes/concentration ( 3 replicates +1 control). The control was exposed to the same laboratory conditions of the treatments, except that no nematode IJs were added to the control. Inspection was carried out at 24, 48 , and $72 \mathrm{~h}$ to record the mortality percentage. The presence of the nematodes inside the insect cadavers were ensured by inspection to confirm the nematode's infection. The mortality was corrected using Abbott's formula (Abbott 1925).

\section{Statistical analysis}

Recorded data of the mortality rates were corrected, using Abbott's correction (Abbott 1925). Statistical analysis was done using analysis of variance (ANOVA) by SAS program 1999.

\section{Results and discussion}

Susceptibility of immature stages of $S$. littoralis and $A$. ipsilon to EPNs

\section{The bioassay of Steinernema monticolum}

The data obtained from Table 1 show that the susceptibility of $S$. littoralis 2nd larval instar to infection with the nematode $S$. monticolum, after $72 \mathrm{~h}$ with the concentrations 50,100, 200, 400, 800, and $1600 \mathrm{IJs} / \mathrm{dish}$, was $77.78,83.33,88.66,91.11,100$, and $100 \%$ of percentage mortalities, respectively. However, Table 2 shows that 


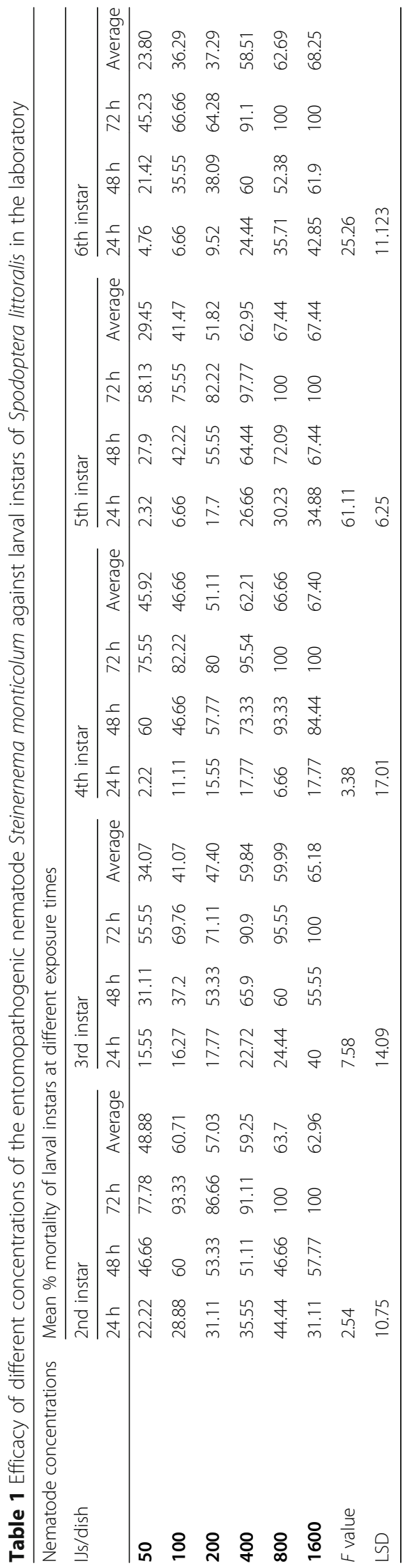




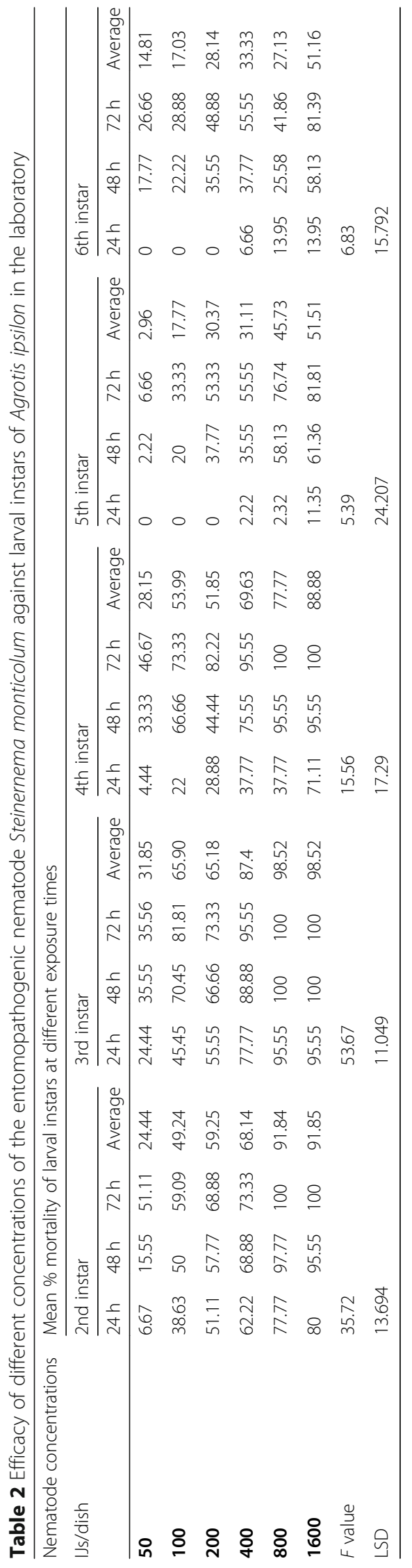




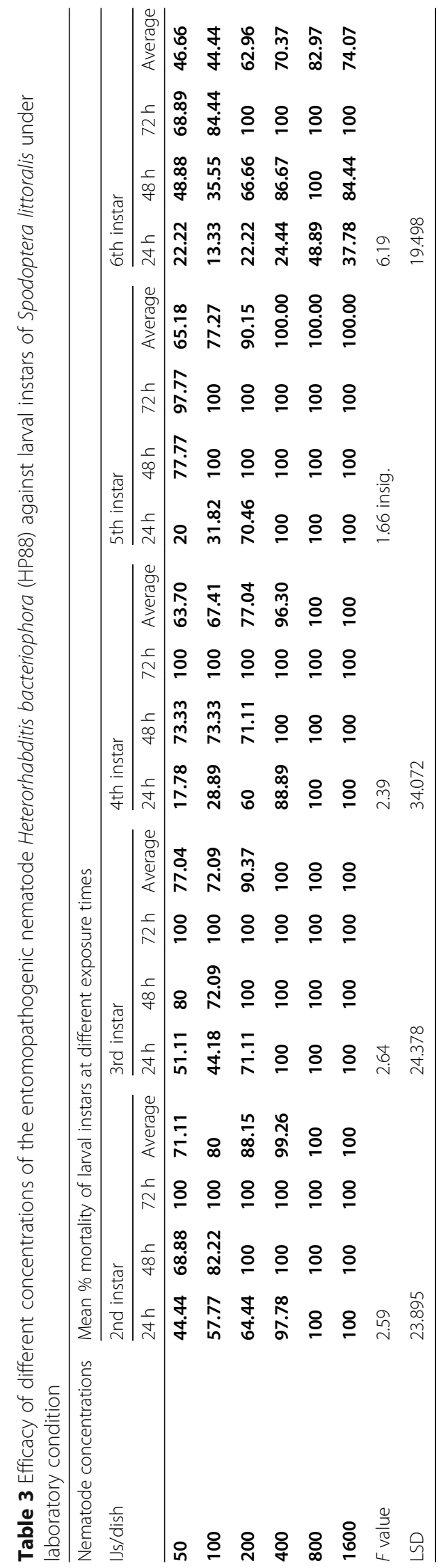




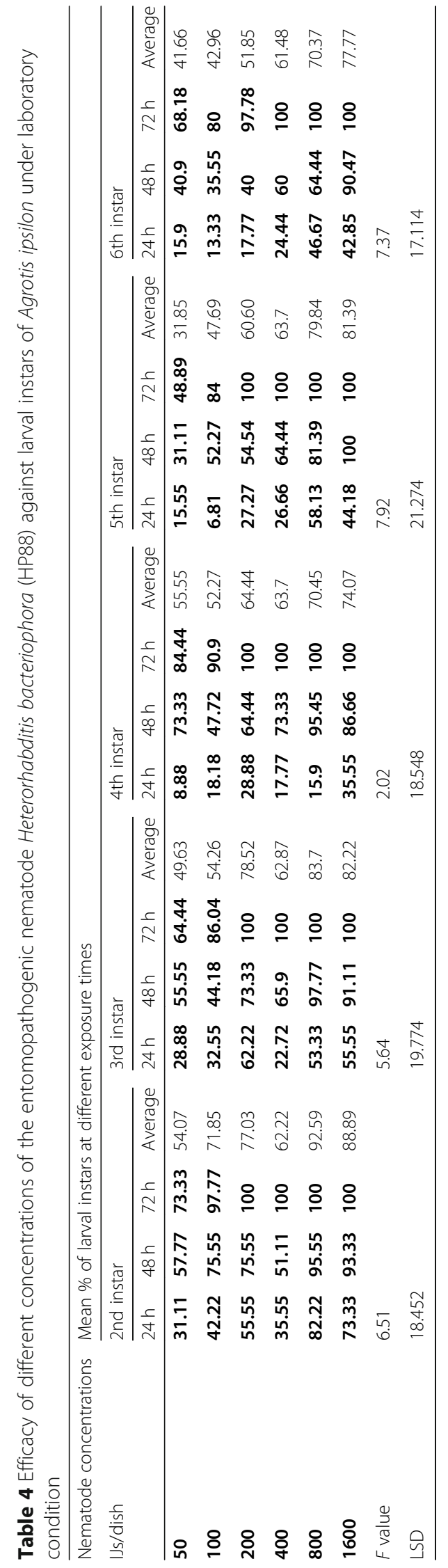


the susceptibility of A. ipsilon 2nd larval instar to infection with the nematode $S$. monticolum, after $72 \mathrm{~h}$ with the concentrations 50,100, 200, 400, 800, and 1600 IJs/ dish, was $51.11,59.09,68.88,73.33,100$, and $100 \%$ of percentage mortalities, respectively.

The obtained results indicated that the 2nd instar of both larval insects was of high susceptibility than the other larval instars, in addition to the ones under the tested concentrations of EPNs.

Mortality rates were much higher in S. littoralis than in A. ipsilon after nematode application. This indicated that the 5th and 6th larval instars of S. littoralis were highly susceptible to $S$. monticolum infection than that of $A$. ipsilon under the same conditions.

The susceptibility of immature stages of $A$. ipsilon to $H$. bacteriophora was studied by Ebssa and Koppenhöfer (2012), who recorded a high mortality (90\%) of A. ipsilon larval in laboratory. The mechanisms of nematode infection to insect larvae has been illustrated by Shapiro-Ilan (2009) who stated that once a host is located, the nematodes enter the host through natural opening (spiracles, anus, and mouth) or by directly penetrating through thin layers in the cuticle. Therefore, the direct penetration of the hosts' cuticle commonly occurs in Heterorhabditis that are equipped with a dorsal tooth. Moreover, the $H$. bacteriophora nematode individuals are hermaphrodite; if one is able to enter the cavity of the body insect, it can continue the life cycle and cause death, and this may be discussed in the variety between the larval mortality rates, in the case of using $H$. bacteriophora (HP88) suspension as compared to S. monticolum.

\section{The bioassay of Heterorhabditis bacteriophora (HP88)}

The data obtained from Tables 3 and 4 show that the susceptibility of $S$. littoralis 2nd, 3rd, 4th, 5th, and 6th larval instars infected by $H$. bacteriophora, after $72 \mathrm{~h}$ with the concentrations 50,100, 200, 400, 800, and 1600 IJs/dish, was almost $100 \%$ of percentage mortalities. The results were recorded for $A$. ipsilon 2nd, 3rd, 4th, 5th, and 6 th larval instars to infection above $80 \%$ by $\mathrm{H}$. bacteriophora. Concerning the efficacy of different concentrations of the EPNs, $S$. monticolum and $H$. bacteriophora (HP88), against immature stages of S. littoralis and A. ipsilon in the laboratory, it could be clear that the 2nd-instar larvae of $S$. littoralis were more susceptible to the infection with EPNs. Because the 2ndinstar larvae have a thin cuticle surface, this leads to ease the direct penetration of nematodes; therefore, the full infection requires a low concentration of EPNs to cause death.

Based on the obtained results, in the nematode species of H. bacteriophora (HP88), it is found that the concentration of $200 \mathrm{IJs} /$ dish caused the highest mortality (100\%) for all larval instars of both insects, which agreed with those of Abdel-Razek and Abd-Elgawad (2007) who reported that Heterorhabditis sp. ELG., H. indica, and Heterorhabditis sp. ELB. were with the highest activity, giving a $100 \%$ mortality to $S$. littoralis larvae in a Petri dish assay after $24 \mathrm{~h}$ post exposure, while $S$. monticolum caused the highest mortality rate for larvae $(100 \%)$ at the concentration of $1600 \mathrm{IJs} /$ dish for all larval instars. Despite the results obtained from Hassan et al. (2016) who reported that the effect of $S$. glaseri was greater than the nematode, $H$. bacteriophora, the obtained results agree with those of Shairra and Nouh (2014) who reported that higher concentrations of nematodes caused an acute effect, while the latent effect was observed in the case of lower ones and Shairra (2007) who found a positive relationship between concentration and larval mortality, mainly due to the concentration of IJs. However, the defense reactions against the nematodes and their associated bacteria may play an important role. EL-Bishry et al. (2002) demonstrated that nematode dose, IJs age, expos. Similar results were obtained by Shamseldean et al. (1995) who recorded that $H$. bacteriophora (HP88) achieved $64 \%$ at $35{ }^{\circ} \mathrm{C}$ to $100 \%$ at $25{ }^{\circ} \mathrm{C}$ mortality of $S$. littoralis.

\section{Conclusion}

The main objective of this research is to work on producing medicinal and aromatic crops (basil), which are in great demand, whether for export of pharmaceutical and aromatic industries, which is necessary to non-use of chemicals in production processes, especially for pest control. Therefore, extensive studies have been conducted in the field of biological control of insect pests, using many bio-control agents such as (EPNs). It is possible to rely on the results of this research in preparation for use in field application for safe control of pests.

\section{Abbreviations Co: Control \\ Acknowledgements \\ Not applicable}

GDP: Gross domestic product; BCW: Black cutworm;

EPNs: Entomopathogenic nematodes; IJs: Infective juveniles; RH\%: Relative humidity; HP88: Strain of Heterorhabditis bacteriophora;

EPN: Entomopathogenic nematode; $n$ : Insect numbers; T: Treated;

\section{Authors' contributions}

All authors contributed 100\% participation. The authors Hassan M. Sobhy, Nagwa A. Abdel-Bary, Farid A. Harras, Farha H. Faragalla, and Hussein I. Husseinen contributed the following: suggesting and putting the idea, preparing the manuscript writing and finishing the paper, and data analysis. The authors read and approved the final manuscript.

Funding

No funding

Availability of data and materials Not applicable 
Ethics approval and consent to participate

Not applicable

\section{Consent for publication}

Not applicable

\section{Competing interests}

The authors declared that the present study was performed in the absence of any conflict of interest or competing interests.

\section{Author details}

'Department of Natural Resource, Faculty of African Post Graduate Studies, Cairo University, Giza, Egypt. ²Department of Zoology and Agricultural Nematology, Cairo University, Faculty of Agriculture, Giza, Egypt.

${ }^{3}$ Department of Vegetable, Medicinal, Aromatic and Ornamental Plant Pests, Plant Protection Research Institute, Agricultural Research Center, Giza, Egypt.

Received: 21 March 2020 Accepted: 17 May 2020

Published online: 15 June 2020

\section{References}

Abbott WS (1925) A method of computing the effectiveness of an insecticide. Econ Entomol 18:265-267

Abdel-Razek AS, Abd-Elgawad MM (2007) Investigation on the efficacy of entomopathogenic nematodes against Spodoptera littoralis (Biosd.) and Galleria mellonella (L.). Arch Phytopathol Plant Protect 40(6):414-422

Atwa, AA., (2011). Mode of actions and field applications of entomopathogenic nematodes, In "Microbial insecticides: principles and applications" (Eds.) J. Francis Borgio, K. Sahayaraj \& I. Alper Susurluk, pp: 211 - 236, Nova Science Publishers, Inc. New York, USA

Atwa AA (2014) Entomopathogenic nematodes as biopesticides. In: Sahayaraj K (ed) Basic and applied aspects of biopesticides. Springer, India, pp 69-98. https://doi.org/10.1007/978-81-322-1877-7_5

Ebssa, L. and Koppenhöfer, A.M. (2012). Entomopathogenic nematodes for the management of Agrotis ipsilon: effect of instar, nematode species and nematode production method. 68: 947-957.

Ehlers R (2001) Mass production of entomopathogenic nematodes for plant protection. Appl Microb Technol 56:623-633

El-Bishry MH, El-Assal FM, Abd El-Rahman RM (2002) Factors affecting penetration rate of the entomopathogenic nematodes Heterorhabditis spp. Egypt J Biol Pest Cont 12(1):25-38

El-Sheikh TAA, Rafea HS, El-Aasar AM, Ali SH (2013) Biological and biochemical effects of bacillus thuringiensis, Serratia marcescens and Teflubenzuron on cotton leafworm. Egypt J Agric Res 91(4):1327-1345

Glaser RW, Farrell CC (1935) Field experiments with the Japanese beetle and its nematode parasite. Journal New York Entomology, Society 43:345-371

Ugur Gozel and Cigdem Gozel (2016) Entomopathogenic nematodes in pest management. In: Harsimran Gill, Gaurav Goyal (eds) Integrated Pest Management (IPM): Environmentally Sound Pest Management. BoD - Books on Demand,

Griffin CT, Boemare NE, Lewis EE (2005) Biology and behaviour. In: Grewal PS, Ehlers R-U, Shapiro-Ilan DI (eds) Nematodes as biocontrol agents. CABI Publishing, Wallingford, UK, pp 47-75

Hassan HA, Shairra SA, Ibrahim SS (2016) Virulence of entomopathogenic nematodes Steinernema glaseri and Heterorhabditis bacteriophora Poinar (HP88 strain) against the black cutworm, Agrotis ipsilon. Egypt Acad J Biolog Sci 9(1):33-48

Ibraheem, H. I. H. (2015) Entomopathogenic nematodes as biocontrol agents of Tuta absoluta on tomato plants M.Sc. Thesis Fac. Agric., Cairo Univ.80 pp.

Kaya HK, Stock SP (1997) Techniques in insect nematology. In: Lacey LA (ed) Manual of techniques in insect pathology. Academic Press, San Diego, pp 281-324

Mutegi, D. M.; Dora, K.; John, W. K. and Charles, W. ( 2018). Integrated use of Kenyan entomopathogenic nematodes (Steinernema species) and neem against Tuta absoluta on tomato. International Journal of Research in Agricultural Sciences.(4): 2348 - 3997

Orozco, R.A.i Lee M. and Stock S. P. (2014). Soil sampling and isolation of entomopathogenic nematodes (Steinernematidae, Heterorhabditidae). J. Vis. Exp. (89): e52083 | Page 1 of 8

SAS Institute. 1999. SAS/STAT. guide for personal computers. SAS Institute.
Shairra, S. A. (2007). Effects of entomopathogenic nematodes and some pharmaceutical inhibitors of eicosanoid biosynthesis on the desert locust Schistocerca gregaria (Forskal).( Ph. D. Thesis, Fac. Sci., Cairo Univ., Egypt, 65.

Shairra SA, Nouh GM (2014) Efficacy of entomopathogenic nematodes and fungi as biological control agent against the cotton leaf worm, Spodoptera littoralis (Boisd.). Egyptian Journal of Biological Pest Control 24(1):247-253

Shamseldean MM, Abd-Elgawad MM, Atwa AA (1995) Evaluation of four entomopathogenic nematodes against Spodoptera littoralis (Lepid., Noctuidae) larvae under different temperatures. Anzeiger Schadlingskde, Pflanzenschutz, Umweltschutz 69:111-113

Shapiro-llan DI (2009) Characterization of biological traits in the entomopathogenic nematode Heterorhabditis georgiana (Kesha strain), and phynology analysis of the nematode's symbiotic bacteria. Biol Control 51:387

Shapiro-llan DI, Gough DH, Piggott SJ, Patterson Fife J (2006) Application technology and environmental considerations for use of entomopathogenic nematodes in biological control. Biol Control 38:124-133

StocK SP, Choo HY, Kaya HK (1997) An entomopathogenic nematode, Steinernema monticolum (Rhabditida: Steinernematidae) from Korea with a key to other species. Nematologica 43:15-29

Stuart RJ, Polavarapu S, Lewis EE, Gaugler R (1997) Differential susceptibility of Dysmicoccus vaccinii (Homoptera: Pseudococcidae) to entomopathogenic nematodes (Rhabditida: Heterorhabditidae and Steinernematidae). Econ Entomol 90:925-932

van Zy C, Malan AP (2014) The role of entomopathogenic nematodes as biological control agents of insect pests, with emphasis on the history of their mass culturing and in vivo production. African Entomology 22(2):235-249

Woodring JL, Kaya HK (1998) Steinernematid and heterorhabditid nematodes: a handbook of techniques. Arkansas Agricultural Experiment Station, Fayetteville, Arkansas. South Cooper Bull 331:1-30

Zhang M, Demeshko Y, Dumbur R, Iven T, Feussner I, Lebedov G, Ghanim M, Barg R, Ben-Hayyim G (2019a) Elevated a-linolenic acid content in extraplastidial membranes of tomato accelerates wound-induced jasmonate generation and improves tolerance to the herbivorous insects Heliothis peltigera and Spodoptera littoralis. J Plant Growth Regul 38:723-738

Zhang Z, Xu C, Ding J, Zhao Y, Lin J, Liu F, Mu W (2019b) Cyantraniliprole seed treatment efficiency against Agrotis ipsilon (Lepidoptera: ctuidae) and residue concentrations in corn plants and soil. Pest Manag Sci 75:464-1472

\section{Publisher's Note}

Springer Nature remains neutral with regard to jurisdictional claims in published maps and institutional affiliations.

\section{Submit your manuscript to a SpringerOpen ${ }^{\circ}$ journal and benefit from:}

- Convenient online submission

- Rigorous peer review

- Open access: articles freely available online

- High visibility within the field

- Retaining the copyright to your article

Submit your next manuscript at $>$ springeropen.com 